\title{
A review study on Uttarabasti of Kumari Taila in the management of Vandhyatva w.s.r. Fallopian Tubal blockage
}

\author{
Review Article
}

\section{Hetal P Baraiya ${ }^{1^{*}}$, Shilpa B Donga ${ }^{2}$, Dei L P $^{3}$, Kashyap Chauhan ${ }^{4}$}

1. Lecturer, Dept. of Streeroga \& Prasootitantra, Shri Gulabkunverba Ayurved Mahavidhyalaya, Jamnagar.

2. Associate Professor, 3. Head of the Department, Department of Streeroga \& Prasootitantra,

4. PhD Scholar, Dept. of Basic Principle,

I.P.G.T. and R.A., Gujarat, Jamnagar -361008

\begin{abstract}
Tubal blockage is one of the most essential causative factors for female infertility. It is the need of the era that a secure, more expenditure effectual and absolute therapy of this sensitive problem should be developed. This review study is an attempt to evaluate the efficacy of Kumari Taila Uttarabasti in tubal blockage. Patients of child bearing age with active marital life of 1 year or more having complaint of failure to conceive with at least one fallopian tube blocked diagnosed by Hysterosalpingography (HSG) were selected. The data of Total four studies of different scholars has been taken for review is being presented here. Out of total 67 registered patients, 61 patients completed the course of treatment, with $53.73 \%$ unilateral and $46.27 \%$ bilateral tubal blockage. Kumari Taila (5 $\mathrm{ml}$ ) Intrauterine Uttarabasti was given for 6 days (with interval of three days in between), after completion of menses for two consecutive cycles. The tubal patency was found in $62.69 \%$ of patients and conception was achieved in $20.90 \%$ without any complication. Uttarabasti is an imperative and an exclusive Ayurvedic procedure stated in classics particularly for the management of Vandhyatva and other gynecological disorders. Kumari Taila Uttarabasti is a highly effective procedure for treating tubal blockage with no apparent evidence of complication.
\end{abstract}

Keywords: Hysterosalpingography (HSG), Intrauter ine Uttarabasti, Kumari Taila, Tubal blockage.

\section{Introduction}

Infertility is the failure to conceive (regardless of cause) after one year of unprotected intercourse. It affects approximately $10-15 \%$ of reproductive aged couples. Among the responsible factors of female infertility, tubal blockage is the second highest i.e. 25$35 \%$ and one of the most notorious factors and very difficult to treat.(1) The management alternatives for it are only tubal reconstructive surgeries and In vitro fertilization (IVF) and available in a very few infertility clinics in developing countries which are not easily accessible. Probability of ectopic pregnancy and other complications are also there. On the other hand, no one has established any reliable Ayurvedic treatment for the tubal blockage. Eventhough, Ayurvedic practitioners assert the effect of intra uterine Uttarbasti on tubal blockage. Hence it was planned that the review study of four research works from I.P.G.T. and R.A., Jamnagar has been done for establishing a

\section{*Corresponding Author:}

\section{Hetal P Baraiya}

Lecturer, Dept. of Streeroga \& Prasootitantra, Shri Gulabkunverba Ayurved Mahavidhyalaya, Gujarat Ayurved University, Jamnagar -361008.

Mobile No.: +91-9428986145

E-mail: het.baria@gmail.com significant data based treatment regimen for tubal blockage through Ayurveda.

\section{Aims and objectives}

This review study is an attempt to evaluate the efficacy of Kumari Taila Uttarabasti in the management of fallopian tubal blockage.

\section{Materials and Methods}

Patients attending the O.P.D. of Stree Roga \& Prasooti Tantra department, fulfilling the criteria for selection were incorporated into the study irrespective of caste, religion etc. A special research proforma was prepared. Total four research works have been reported in I.P.G.T. \& RA, Jamnagar. From them, Total 67 patients were registered, out of them 61 patients completed the course of treatment. All the patients were examined per vaginally to assess any sign of infection or disorder related to tubal infertility.

\section{Criteria for selection of cases Inclusion criteria:}

Patients of child bearing age having complaints of failure to conceive due to tubal blockage were selected for the study, on the diagnostic basis of Hysterosalpingography (HSG) for minimizing the chances of false positive reports. 


\section{Exclusion criteria:}

Patients with any possibility of active urogenital infections, history of excessive menstruation, suffering from any chronic disease, Hepatitis B, sexually transmitted disease, human immunodeficiency virus (HIV), contagious diseases etc. were excluded.

\section{Investigations:}

Serological tests for HIV (Human Immunodeficiency Virus), HBsAg (Australia antigen for hepatitis B) \& VDRL (Venereal Disease Research Laboratory) were carried out in all the patients before starting the course of treatment.

Transvaginal sonography was done before treatment to rule out any pelvic pathology.

Routine haematological and urine investigations were done before and after treatment.

\section{Selection of drug}

Tubal blockage has been considered as the Vata predominant Tridoshaja condition, with Kapha as being the next Dosha, as Vata was responsible for Sankocha,

(2) Kapha for Shopha and Puya while Pitta for Paka. (3) Thus, all the three Doshas are collectively responsible for the stenosis or the hampering type of pathology of the fallopian tubes. The drug assumed as effective to open the fallopian tube was considered to have Tridoshaghna properties mainly Vatakaphashamaka. Local administration of any drug which containing Sukshma, Laghu, Sara, Vyavayi, Vikasi, Pramathi etc. Guna; Katu Vipaka \& Ushna Virya can be assumed to have some effective role in removing tubal blockage and to restore the tubal functions by reaching up to the minute channels. It is mentioned for Vata Kaphaja Shiroroga.(4) It includes various drugs effective in gynaecological disorders. Several contents of Kumari Taila are highly efficacious $\&$ established for their role in menstrual disorders and hormonal imbalance.

\section{Treatment protocol}

Uttarbasti of Kumari Taila (five milliliters) was given for six days (with interval of three days in between), after cessation of menses for two consecutive cycles,(5) with the consent of the patient. Snehana (oleation) of Bala Taila(6) followed by Nadi Sveda (fomentation) with water steam was done on the lower abdomen, back and lower limbs to the patients, before each Uttarbasti. For sterilization of peri vaginal part Yoni Prakshalana with Panchavalkala Kvatha(7) was performed. The procedure was carried out in the operation theatre with all antiseptic and aseptic precautions and then the patient was kept in head low for two hours. The lower abdomen was fomented with hot water bag. The HSG was repeated for the analysis of results after the cessation of menstruation in third cycle.

\section{Precautions}

The patients were asked to avoid very spicy food during treatment. Coitus was prohibited during the course of Uttarabasti. Proper care was taken for not allowing patients to suffer from constipations.

\section{Assessment of complications}

The chances of complications cannot be ignored totally, because the Taila prepared with Ushna-Tikshna Dravyas was administered inside the uterus. Lower abdominal pain and per vaginal bleeding were the most apparent complaints during and after procedure. It was considered as complication, only if it is was very much irritating for the patient. Any type of features of urogenital infection during and after procedure was considered as complication. Hence, close study was kept to detect complications as early as possible.

\section{End points of the treatment}

- If the patient conceives in between the course of study.

- If features of any type of urogenital infections are observed.

- If heavy per vaginal bleeding creates.

- If there occurs severe abdominal pain, which troubles the patient to a great extent.

\section{Follow-up study}

Follow-up study for pregnancy or any late complication was carried out for two months after the completion of treatment. Any new complaint appears during follow up period related to study was also noted.

Observations and Results (8),(9),(10),(11):

Chart 1. Types of Infertility $(\mathrm{N}=67)$

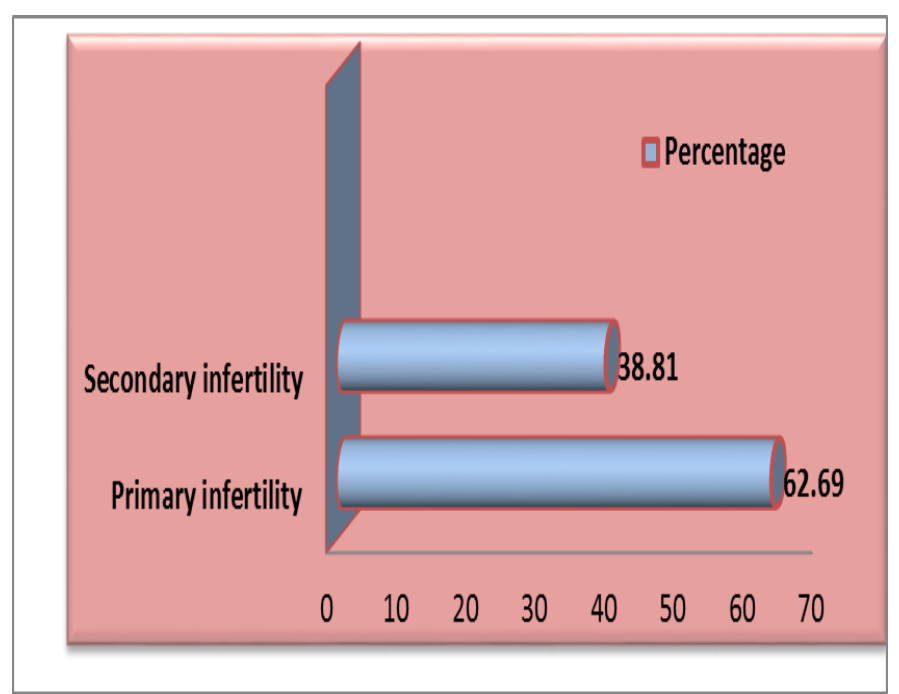


Chart 2. Types of Tubal Blockage $(N=67)$

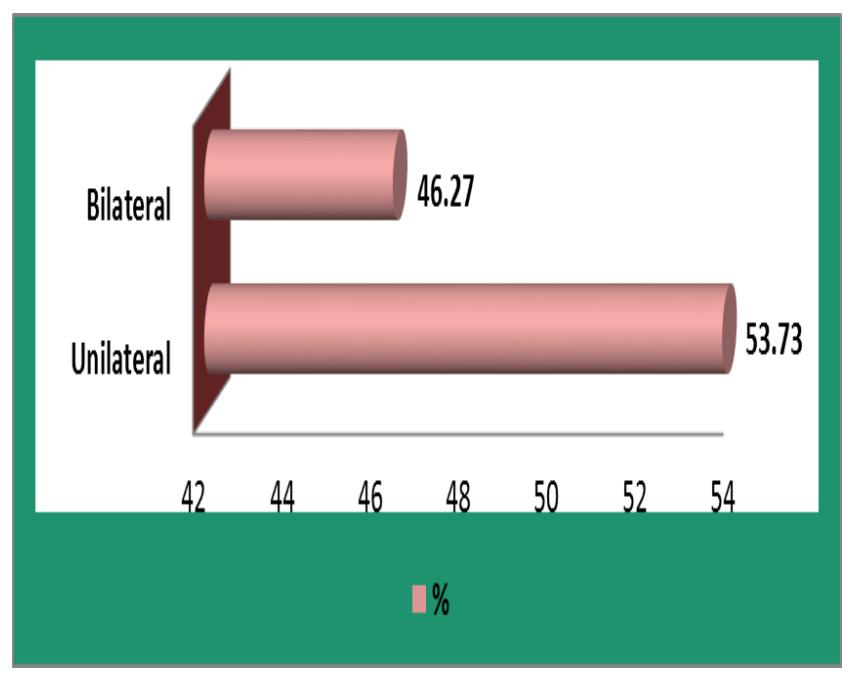

Chart 3. Tubal Patency after Uttarabasti $(\mathrm{N}=61)$

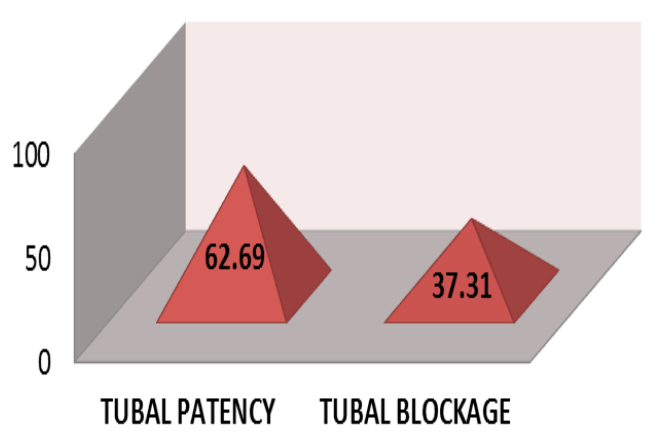

$\square$

Chart 4. Patients, who conceived within follow up $\operatorname{period}(\mathrm{N}=61)$

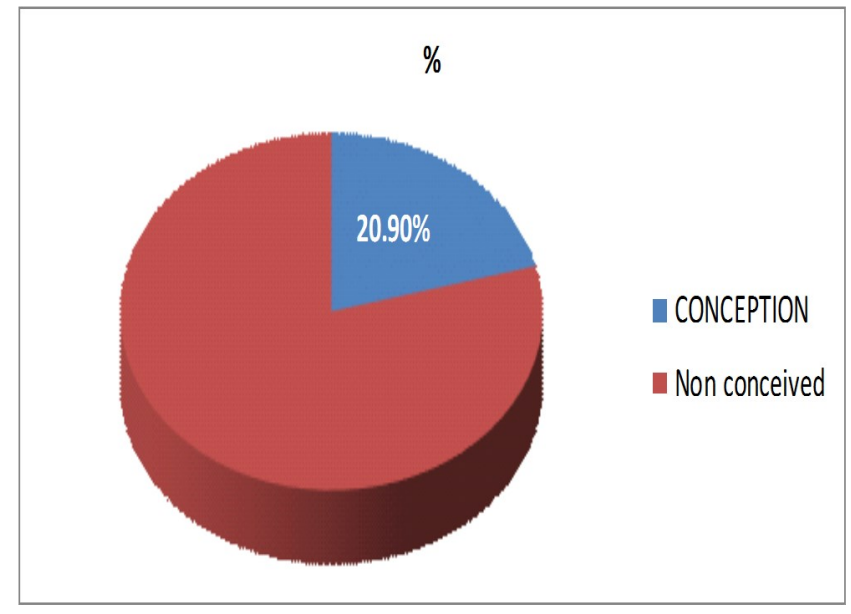

\section{Discussion}

While considering the history of infertility, the $62.69 \%$ patients were found with the primary infertility [Chart 1]. It is a trend in many gynecology clinics that tubal blockage is evaluated at last after long term of ovulation induction and other treatment. But, this data shows the change in trend, at least in our institution where tubal factor is given prime importance as preliminary investigation. It also disproves the general belief that some infection during previous labour or abortion is the major cause of tubal blockage. Since tubal blockage is quite prevalent even in patients with primary infertility, it should not be neglected and must be evaluated after some cycles of treatment before allowing the condition to get much complicated due to several inductions. There was not much significant difference observed in unilateral \& bilateral tubal blockage. The incidence of unilateral \& bilateral tubal blockage in the present study shows the prevalence of both the conditions high in the society [Chart 2]. Yet unilateral blockage is also important to give due consideration, because, it reduces the possibility of conception. And the condition becomes worse, if another patent tube is not normal physiologically. The contractile response was confirmed by the lower abdominal pain, which was a common complaint after procedure. No patient had excessive or fresh bleeding. It proves the removal of the inner uterine as well as tubal lining by the Ushna-Tikshna and Lekhana properties of drugs. Symptoms of genitourinary infection and oil embolism were not reported during and after procedure and even in the follow up period in any patient of four research works, which is the most probable complication of Uttarabasti. It was because of the potent anti-inflammatory and anti-infective effect of Tila Taila which is used as a vehicle in the drug. It proves the intra uterine Uttarabasti as a safe therapeutic measure against tubal blockage. Tubal blocks were removed in $62.69 \%$ patients and conception was achieved in $20.90 \%$ patients within the follow-up period [Chart 3-4]. This total effect of therapy was very encouraging and highly significant on tubal blockage. It shows the potency of the drugs used and also the efficacy of Uttarabasti. Conception rate is less as it is a problem involving multiple factors like anovulation, PCOD, male factors etc. Most of the patients had taken exclusively Allopathic treatment. History of D and C or $\mathrm{D}$ and $\mathrm{E}$ was found in less than $40 \%$ patients. The most common site was Cornual block in all four studies.

\section{Probable mode of action of intra uterine Uttarabasti on tubal blockage}

All three Doshas are involved in the pathogenesis of tubal block with predominance of Vata Dosha. Kapha is also one of the responsible factors for vitiation of Vata due to its Avarodhatmaka Guna. Vata vitiated on its own as well as by Kapha which is able to vitiated Vata by its property to cause Avarodha. For administration of the drug in tubal blockage, a medium is always required. The medium adapted must not be having any adverse effect in Samprapti Vighatana and it would be more appreciable, if it will contain some adjuvant role to open tubal blockage. So, Tila Taila was 
selected for this purpose, as it has most of the qualities, which were required for the present study. Several contents of Kumari Taila are highly efficacious \& established for their role in menstrual disorders and hormonal imbalance. In case of tubal blockage, effect seems to be more local than systemic. The Tila Taila (12),(13),(14),(15) is Vranashodhaka \& Vranapachaka. It is Krimighna too. In addition, its specific role on uterus and reproductive tract is also mentioned as Garbhashayashodhana \& Yonishulaprashamana. These all the properties indicate towards its antiseptic as well as anti-inflammatory actions. Its Vyavayi \& Vikasi Guna show its potency to enter in minute channels and to get spread easily. Thus, it should be the best medium for any drug to reach in tubal cavity and remove the blockage. Kumari (Aloe vera) (16),(17),(18) is now well established for its anti-inflammatory, ulcer-healing and antibacterial properties. It is Tikshna and VataKaphavardhaka in Karma. Thus, it removes the fibrosis of endometrium and helps in its rejuvenation. Its Antiinflammatory action decreases the inflammation and ulcer-healing property heals the inner lining of tubes and uterus. The another important content of Kumari Taila, Bhringaraja (Eclipta alba) (19) is a very potent VataKapha Shamaka drug, which contains antiviral, antibacterial, antioxidant and antihaemorrhagic qualities. All these properties make the medicine more potent in removing the chronic inflammation and fibrosis. Its Shothahara \& Vishahara Karma reduce swelling and oedema of the tube and render it in a healthier atmosphere. Another major content of Kumari Taila, Dhatura (Datura metel) (20),(21),(22) is Krimighna, Vranahara \& Vishaghna. It is known for its anti-inflammatory property and hence, it hastens the healing and rejuvenation of the inner lining of tubes.

\section{Conclusion}

The results suggest that Uttarabasti is a safe, reliable \& efficacious measure in management of tubal infertility. Kumari Taila is a highly effective to achieve the patency of fallopian tubes. Chances of complications are negligible, if proper antiseptic and aseptic care is taken before, during \& after the procedure. Rate of conception within follow up period shows high chances of pregnancy, if other factors are normal.

\section{References}

1. Dutta.D. C. Textbook of Gynaecology. $5^{\text {th }}$ ed. New Central Book Agency;2009:222p.

2. Acharya Kashyapa, Pandita Hemraja Sharma. Kashyapa Samhita, Vidyotini Hindi commentary. Varanasi, Chaukhamba Sanskrit Sansthan;2009:Sutra Sthana 27:30-31p.

3. Acharya Sushruta, Shastri Ambika Dutta. Sushruta Samhita, Ayurveda-Tattva-Samdipika vyakhya. Varanasi, Chaukhamba Sanskrit Sansthan;2006:Sutra Sthana 17:12.
4. Shri Bhavamishra, Pandit Shri Brahma Shankara Mishra. Bhava Prakasha, Vidyotini Hindi commentary. 11ed. Varanasi;Chaukhambha Sanskrita Bhavana, Madhyama Khanda, Shirorogadhikara; 2009. 612-613p.

5. Acharya Agnivesha, Kashinath Shastri, Gorakhnath Chaturvedi. Charaka Samhita, Vidyotini Vyakhya. Varanasi, Chaukhambha Bharati Academy; 2005:Siddhi Sthana 9:69.

6. Vagbhatacharya, Srikantha Murthy. Ashtanga Hridaya. Varanasi, Krishnadasa Academy; 2006:Chikitsa Sthana 21:73-81.

7. Sharangdharacharya, Brahmananda Tripathi. Sharangadhara Samhita, Dipika Hindi Vyakhya. Varanasi, Chaukhambha Surabharati Prakashana; 2008: Madhyama Khanda;2:149:155p.

8. Kamayani Shukla. A comparative study of Uttarabasti of Yava Kshara Taila \& Kumari Taila in Tubal blockage. I.P.G.T.\&R.A., Jamnagar;Gujarat Ayurved University;2010.

9. Neha Mamgein. (2009-2012)A comparative study of Uttarabasti of Yava Kshara Taila \& Kumari Taila in Tubal blockage. I.P.G.T.\&R.A., Jamnagar;Gujarat Ayurved University;2012.

10. Hetal Baria. A further study on Uttarabasti of Yava Kshara Taila \& Kumari Taila in the managementof Vandhyatva w.s.r. To tubal blockage. I.P.G.T.\&R.A., Jamnagar;Gujarat Ayurved University;2013.

11. Jigisha Baldha. A further study on Uttarabasti of Kumari Taila \& Tila Taila in the management of Vandhyatva w.s.r. To tubal blockage. I.P.G.T.\&R.A., Jamnagar;Gujarat Ayurved University;2014.

12. Shri Bhavamishra, Pandit Shri Brahma Shankara Mishra, Shri Rupalalaji Vaisya. Bhava Prakasha Nighantu, Vidyotini Hindi commentary. 11ed. Varanasi;Chaukhambha Sanskrita Bhavana;Taila Varga;2007. 779p.

13. Shri Bhavamishra, Pandit Shri Brahma Shankara Mishra, Shri Rupalalaji Vaisya. Bhava Prakasha Nighantu, Vidyotini Hindi commentary. 11ed. Varanasi;Chaukhambha Sanskrita Bhavana;Dhanya varga;2007. 651-652p.

14. Anonymous. Govt. of India, Ministry of Health \& Family Welfare, dept. Of ISM \& H. The Ayurvedic Pharmacopeia of India. New Delhi, 2006:4:143p.

15. Sushruta, Yadavaji Trikamji Acharya, Narayana Ram Acharya. Shushruta Samhita, Dalhana commentary. Varanasi;Chaukhambha Surbharati Prakashana;2012. 205p.

16. Shri Bhavamishra, Pandit Shri Brahma Shankara Mishra, Shri Rupalalaji Vaisya. Bhava Prakasha Nighantu, Vidyotini Hindi commentary. 11ed. Varanasi;Chaukhambha Sanskrita Bhavana; Guduchyadi varga;2007. 419p.

17. Anonymous, Govt. of India. Dept. of ISM\&H, Ministry of Health \& Family Welfare. Database on 
International Journal of Ayurvedic Medicine, 2015, 6(3), 197-201

Medicinal plant used in Ayurveda C.C.R.A.S. New Delhi;2000;Vol.1:225p.

18. Vd. Mukund Sabnis. Chemistry and Pharmacology of Ayurvedic medicinal plants. Varanasi; Chaukhamba Amarbharti Prakashana;2006. 100p.

19. Anonymous, Govt. of India. Dept. of ISM\&H, Ministry of Health \& Family Welfare. Database on Medicinal plant used in Ayurveda C.C.R.A.S. New Delhi;2000;Vol.2e:112p.

20. Shri Bhavamishra, Pandit Shri Brahma Shankara Mishra, Shri Rupalalaji Vaisya. Bhava Prakasha
Nighantu, Vidyotini Hindi commentary. 11ed. Varanasi;Chaukhambha Sanskrita Bhavana; Guduchyadi varga;2007. 317p.

21. Anonymous, Govt. of India. The Ayurvedic Pharmacopeia of India. First edition, New Delhi;2006; volume 4:29p.

22. Anonymous, Govt. of India. Dept. of ISM\&H, Ministry of Health \& Family Welfare. Database on Medicinal plant used in Ayurveda C.C.R.A.S. New Delhi;2000;Vol.2e:200p. 